\title{
ノート
}

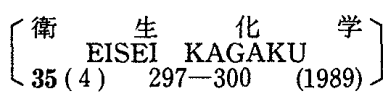

- Notes -

\section{Investigation of Interference by Inorganic Phosphate on Coprecipitation of Cadmium, Copper, Manganese and Lead in Water with Zirconium Hydroxide}

\author{
Takako Osanal, Kumi Hayakawa, Naomi Kikuchi, Shigeko Konno, Kota Ito, \\ Nobuyuki Shibata and Shigeo Suzuki
}

Second Department of Hygienic Chemistry, Tohoku College of Pharmacy, Sendai 981, Japan

(Received January 5,1989$)$

The interference effect of $\mathrm{PO}_{4}{ }^{3-}$ on the recovery of $\mathrm{Cd}, \mathrm{Cu}, \mathrm{Mn}$ and $\mathrm{Pb}$ in water during determination by coprecipitation with $\mathrm{Zr}(\mathrm{OH})_{4}$ followed by flame atomic absorption spectrometry (FAAS) was investigated. Free $\mathrm{PO}_{4}{ }^{3-}$ in water, from 0.125 to $1.5 \mathrm{mg} / \mathrm{ml}$, exhibited weak interference on the recovery of these metals, giving rise to errors of a few to several percent in the direct FAAS analysis. In the coprecipitation method, $\mathrm{Zr}^{4+}$ showed an unfavorable property to FAAS, forming a precipitate of phosphate which was insoluble to both water and $(1+1) \mathrm{HCl}$. The above problems were solved by precipitating $\mathrm{PO}_{4}{ }^{3-}$ with $\mathrm{Zr}^{4+}$ followed by washing the precipitate with $(1+1) \mathrm{HCl}$, solubilizing the coprecipitated metals quantitatively, and removing $\mathrm{PO}_{4}{ }^{3-}$ by centrifugation as acid-insoluble $\mathrm{Zr}^{4+}$ salt.

Keywords — quantitative determination; cadmium; copper; manganese; lead ; coprecipitation; zirconium hydroxide ; atomic absorption spectrometry ; phosphate

In an earlier paper by Abe et al., ${ }^{1)}$ it was reported that coprecipitation of metal ions with zirconium hydroxide $\left(\mathrm{Zr}(\mathrm{OH})_{4}\right)$ was quite effective in concentrating $\mathrm{Cd}, \mathrm{Cu}, \mathrm{Mn}$, and $\mathrm{Pb}$ existing in water. In the presence of $\mathrm{PO}_{4}{ }^{3-}$, however, there is a problem in the recovery of metal by this method due to the formation of water-insoluble precipitate with

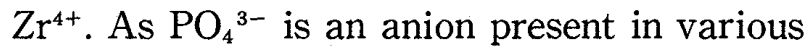
samples collected for metal analysis, we investigated the interference behavior of $\mathrm{PO}_{4}{ }^{3-}$ on the determination of these four metals in deionized water by the sequential adoption of coprecipitation with $\mathrm{Zr}(\mathrm{OH})_{4}$ and flame atomic absorption spectrometry (FAAS).

Materials and Methods

Reagents and Water _ Z Zirconium solution (aqueous $3.53(\mathrm{w} / \mathrm{v} \%)$ solution of $\mathrm{ZrOCl}_{2} \cdot 8 \mathrm{H}_{2} \mathrm{O}$ ) and the standard solution of $\mathrm{Cd}, \mathrm{Cu}, \mathrm{Mn}$ and $\mathrm{Pb}$ were the same as in the earlier paper. ${ }^{1}$ Water used in the present study was tap water deionized by passing through an Organo Puric GA-15-B apparatus.

General Operating Procedure — Fifty $\mathrm{ml}$ of a standard solution of $\mathrm{Cd}, \mathrm{Cu}, \mathrm{Mn}$ and $\mathrm{Pb}, 25$ $\mu \mathrm{g} / \mathrm{l}$, in a $100-\mathrm{ml}$ glass centrifuge tube was acidified with $(1+1) \mathrm{HCl}$ to $\mathrm{pH}$ 1.0. To the solution was added zirconium solution, $1.0 \mathrm{ml}$, and the $\mathrm{pH}$ was adjusted to 10.0 by dropwise addition of 4 $\mathrm{N} \mathrm{NaOH}$. In the presence of $\mathrm{PO}_{4}{ }^{3-}$, the precipitate formed at $\mathrm{pH}$ lower than 3.0. The reaction mixture was then centrifuged at $2000 \mathrm{rpm}$ for $10 \mathrm{~min}$. The supernatant was discarded, and the sediment was washed by centrifuging with $80 \mathrm{ml}$ of deionized water. To the residue was added $4 \mathrm{ml}$ of $(1+$ 1) $\mathrm{HCl}$, the mixture was stirred for $30 \mathrm{~s}$ at room 
temperature on a magnetic stirrer, and deionized water was added to make it $20 \mathrm{ml}$. If any insoluble materials including zirconium phosphate remained, the mixture was centrifuged at 2000 rpm for $10 \mathrm{~min}$. The metal content in the supernatant was then analyzed by FAAS using a Hitachi Z-6100 polarized Zeeman atomic absorption spectrophotometer. Determination was repeated 3 times. Chart 1 summarizes the above process. The analytical conditions of FAAS for $\mathrm{Cd}, \mathrm{Cu}, \mathrm{Mn}$ and $\mathrm{Pb}$ are shown in Table I.

Examination of Interference Caused by $\mathrm{PO}_{4}{ }^{3-}$ - (1) Reaction of $\mathrm{PO}_{4}{ }^{3-}$ with $\mathrm{Zr}^{4+}$ : To $50 \mathrm{ml}$ of deionized water, $\mathrm{pH} \mathrm{1.0,} \mathrm{containing}$ increasing amounts of $\mathrm{PO}_{4}{ }^{3-}$ was added $1.0 \mathrm{ml}$ of zirconium solution, and $\mathrm{pH}$ was adjusted to 5.0 with $4 \mathrm{~N} \mathrm{NaOH}$ with stirring. After centrifugation at $2000 \mathrm{rpm}$ for $10 \mathrm{~min}$ followed by washing with $80 \mathrm{ml}$ of water by centrifugation, the residue was stirred with $4 \mathrm{ml}$ of $(1+1) \mathrm{HCl}$, and the total volume was brought up to $20 \mathrm{ml}$ with deionized water. An aliquot of the mixture was centrifuged at $2000 \mathrm{rpm}$ for $10 \mathrm{~min}$, and phosphate content in the supernatant was analyzed by the Ames-Dubin test solution

metal standard solution, $50 \mathrm{ml}$

$\mathrm{pH} 1.0$ with $(1+1) \mathrm{HCl}$

$\mathrm{ZrOCl}_{2}$ solution $1.0 \mathrm{ml}(\mathrm{Zr}, 10 \mathrm{mg})$

pH 10.0 with $4 \mathrm{~N} \mathrm{NaOH}$

centrifuge for $10 \mathrm{~min}$ at $2000 \mathrm{rpm}$

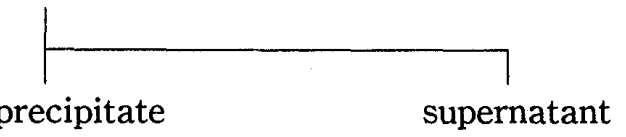

wash with water

dissolve in $(1+1) \mathrm{HCl}, 4 \mathrm{ml}$

bring up to $20 \mathrm{ml}$

centrifuge for $10 \mathrm{~min}$ at $3000 \mathrm{rpm}$

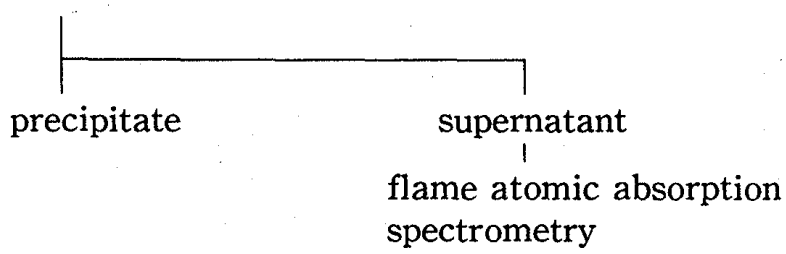

Chart 1. Determination of Metals by Coprecipitation Method with $\mathrm{Zr}(\mathrm{OH})_{4}$ in the Presence of Phosphate method. ${ }^{2)}$

(2) Recovery of Metals in the Presence of $\mathrm{PO}_{4}{ }^{3-}$ : To $50 \mathrm{ml}$ of deionized water, containing increasing amounts of $\mathrm{PO}_{4}{ }^{3-}$ was added $1.0 \mathrm{ml}$ of a standard metal solution, then the mixture was subjected to the coprecipitation method as described in "General Operating Procedure".

\section{Results and Discussion}

In the preceding study, ${ }^{1}$ we conducted a recovery test of $\mathrm{Cd}, \mathrm{Cu}, \mathrm{Mn}$ and $\mathrm{Pb}$ in drinking water by coprecipitation with $\mathrm{Zr}(\mathrm{OH})_{4}$; we observed that the precipitation of these metals started at $\mathrm{pH} 6-7$, and their recovery was not affected by low concentrations of the various cations and anions contained in drinking water ${ }^{3)}$ However, with increase in the amount of $\mathrm{PO}_{4}{ }^{3-}$, the formation of white precipitate was observed even below $\mathrm{pH} 3$, suggesting that $\mathrm{PO}_{4}{ }^{3-}$ forms water-insoluble salt with $\mathrm{Zr}^{4+}$ in an acidic medium. The present study was undertaken to examine the influence of $\mathrm{PO}_{4}{ }^{3-}$ of considerably high con-

TABLE I. Operating Condition for Flame Atomic Absorption Spectrometry (Hitachi Z-6100) ${ }^{a}$ )

\begin{tabular}{lrrrr}
\hline \hline & $\mathrm{Cd}$ & $\mathrm{Cu}$ & $\mathrm{Mn}$ & $\mathrm{Pb}$ \\
\hline Wave length $(\mathrm{nm})$ & 228.8 & 324.8 & 279.5 & 283.3 \\
Lamp current $(\mathrm{mA})$ & 6.0 & 5.0 & 5.0 & 7.5 \\
Slit width $(\mathrm{nm})$ & 1.3 & 1.3 & 0.4 & 1.3 \\
\hline a) Simultaneous background correction was made by the \\
polarized Zeeman effect method. \\
acetylene, $0.3 \mathrm{~kg} / \mathrm{cm}^{2}$. air, $1.6 \mathrm{~kg} / \mathrm{cm}^{2}$.
\end{tabular}

TABLE II . Interference by $\mathrm{PO}_{4}{ }^{3-}$ on Recoveries of $\mathrm{Cd}, \mathrm{Cu}, \mathrm{Mn}$ and $\mathrm{Pb}$ from Deionized Water

\begin{tabular}{ccc}
\hline \hline \multirow{2}{*}{$\begin{array}{c}\text { Amount of } \mathrm{PO}_{4}{ }^{3-} \\
\text { added }(\mathrm{mg} / \mathrm{ml})\end{array}$} & \multicolumn{2}{c}{ Extent of interference $(\%)$} \\
\cline { 2 - 2 } & $\mathrm{Cd}^{a)} \quad \mathrm{Cu}^{b)} \mathrm{Mn}^{c)} \mathrm{Pb}^{d)}$ \\
\hline 0.125 & $+2.6+4.9+0.7+5.0$ \\
0.25 & $+5.1+5.9+3.0+3.7$ \\
0.5 & $+5.5+7.0+2.9+4.5$ \\
1.5 & $+5.9+7.6-0.1+1.6$ \\
\hline
\end{tabular}

a) $50 \mathrm{ng} / \mathrm{ml}$, b) $200 \mathrm{ng} / \mathrm{ml}$, c) $50 \mathrm{ng} / \mathrm{ml}$, d) $200 \mathrm{ng} / \mathrm{ml}$. 
centration on the determination of metals. We first examined the direct interference effect of $\mathrm{PO}_{4}{ }^{3-}$ on the recovery of $\mathrm{Cd}, \mathrm{Cu}, \mathrm{Mn}$ and $\mathrm{Pb}$. Table II summarizes the results of this interference test in water containing $\mathrm{PO}_{4}{ }^{3-}, 0.125$ to $1.5 \mathrm{mg} / \mathrm{ml}$. As seen, $\mathrm{PO}_{4}{ }^{3-}$ with concentration above $0.25 \mathrm{mg} / \mathrm{ml}$ can positively interfere with decrease of the recovery of $\mathrm{Cd}, \mathrm{Cu}$, and $\mathrm{Pb}$ in a few-to several-percent scale. Recovery of $\mathrm{Mn}$ was also shown to undergo interference by $\mathrm{PO}_{4}{ }^{3-}$, although the extent was less than those of other metals. Therefore, the establishment of a procedure to eliminate $\mathrm{PO}_{4}{ }^{3-}$ in metal analysis by FAAS seemed essential. We thus conducted a recovery test of the four metals using coprecipitation with $\mathrm{Zr}(\mathrm{OH})_{4}$ in the hope of establishing a method of eliminating the $\mathrm{PO}_{4}{ }^{3-}$ interference by the formation of water-insoluble precipitate, followed by the dissolution of $\mathrm{Zr}(\mathrm{OH})_{4}$ with dilute acid leaving zirconium phosphate as an insoluble residue. Figure 1 shows the relationship between the amount of precipitated $\mathrm{PO}_{4}{ }^{3-}$ with $\mathrm{Zr}^{4+}$ and $\mathrm{pH}$ of the reaction mixture. It is evident that $\mathrm{Zr}^{4+}$ forms an insoluble precipitate with $\mathrm{PO}_{4}{ }^{3-}$, indicating that the maximum exists at $\mathrm{pH} 5.0$. Therefore, the formation of this precipitate in further recovery tests of $\mathrm{PO}_{4}{ }^{3-}$ was conducted at

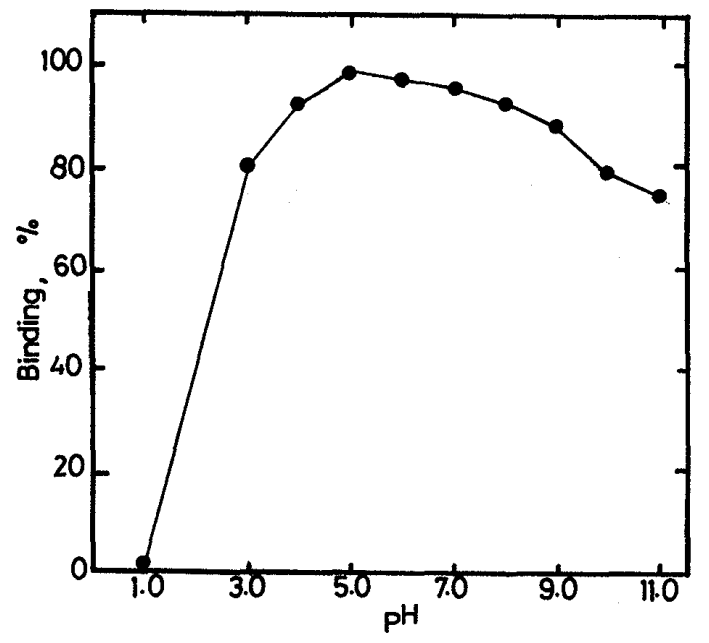

Fig. 1. Relationship between Binding Ratio of $\mathrm{PO}_{4}{ }^{3-}$ and $\mathrm{pH}$ in Coprecipitation with $\mathrm{Zr}(\mathrm{OH})_{4}$ this $\mathrm{pH}$. In order to investigate the influence of extremely large amounts of $\mathrm{PO}_{4}{ }^{3-}$ in water, up to $30 \mathrm{mg} / 50 \mathrm{ml}$, another series of recovery tests of $\mathrm{PO}_{4}{ }^{3-}$ using a fixed amount of $\mathrm{Zr}^{4+}$ was conducted. As shown in Fig. 2 by open circles, the ratio of precipitated $\mathrm{PO}_{4}{ }^{3-}$ in the precipitate decreased rapidly. In other words, $\mathrm{Zr}^{4+}$ in $1 \mathrm{ml}$ of zirconium solution can trap quantitatively up to $10 \mathrm{mg}$ of $\mathrm{PO}_{4}{ }^{3-}$, and the rest of this anion exists in the supernatant. The line with closed circles in the figure indicates the amounts of $\mathrm{PO}_{4}{ }^{3-}$ dissolved from the precipitate by stirring with $(1+1) \mathrm{HCl}$. It is obvious that dissolution of $\mathrm{PO}_{4}{ }^{3-}$ from the precipitate was not quantitative even with the lowest amount of $\mathrm{PO}_{4}{ }^{3-}$, and that the amounts of $\mathrm{PO}_{4}{ }^{3-}$ precipitated from the solutions of higher concentration than $10 \mathrm{mg} / 50 \mathrm{ml}$ were entirely retained in the precipitate even when washed with $(1+1) \mathrm{HCl}$. These results led us to the assumption that interference by $\mathrm{PO}_{4}{ }^{3-}$ might be avoidable if $\mathrm{Zr}(\mathrm{OH})_{4}$ contaminated with a considerable amount of zirconium phosphate can still display the coprecipitating effect of these metals quantitatively. We therefore, conducted a recovery test of the

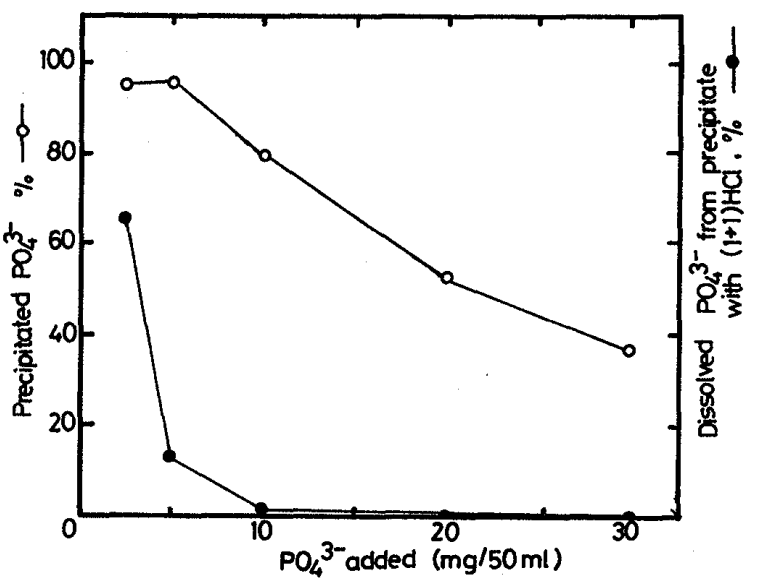

Fig. 2. Relationship between Amounts of $\mathrm{PO}_{4}{ }^{3-}$ in Sample Water and in Supernatant after Coprecipitation with $\mathrm{Zr}(\mathrm{OH})_{4}$ Followed by Treatment of the Precipitate with $(1+1) \mathrm{HCl}$

Amount of dissolved $\mathrm{PO}_{4}{ }^{3-}$ from zirconium phosphate in precipitate with $(1+1) \mathrm{HCl}$. 


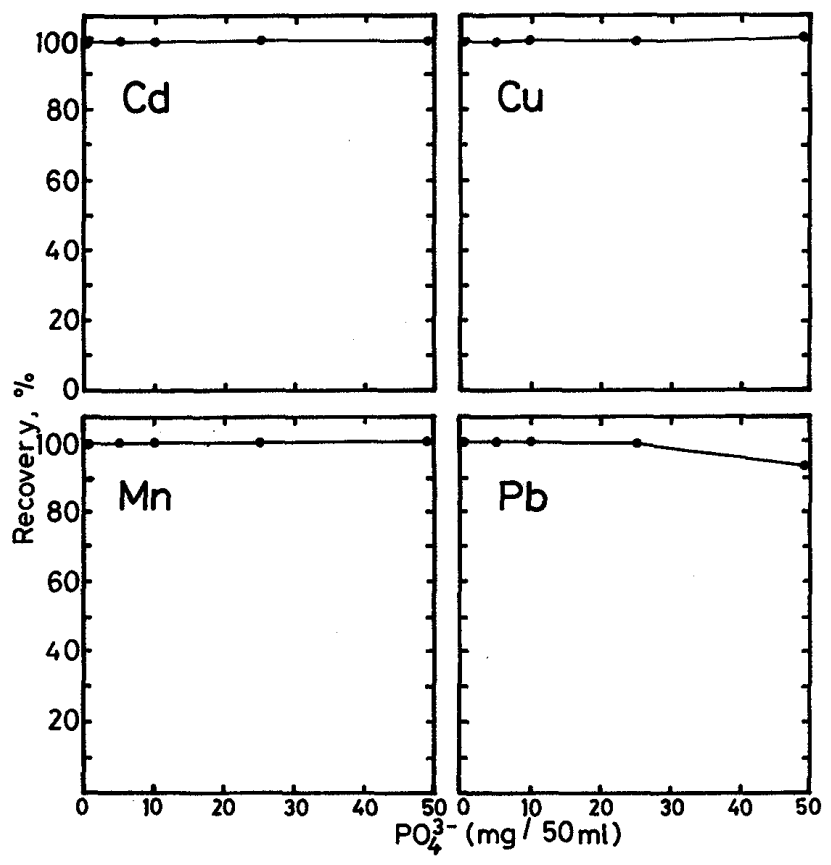

Fig. 3. Recovery Tests of $\mathrm{Cd}, \mathrm{Cu}, \mathrm{Mn}$, and $\mathrm{Pb}$, Each $25 \mu \mathrm{g} / 1$, from Water Containing Less than $1 \mathrm{mg} / \mathrm{ml} \mathrm{PO}_{4}{ }^{3-}$ by Coprecipitation with $\mathrm{Zr}(\mathrm{OH})_{4}$ Followed by FAAS four metals from water containing 5.0 to 50 $\mathrm{mg} / 50 \mathrm{ml}$ of $\mathrm{PO}_{4}{ }^{3-}$. The results depicted in Fig. 3 clearly indicate that interference by $\mathrm{PO}_{4}{ }^{3-}$ is avoidable by coprecipitation with $\mathrm{Zr}^{4+}$, excepting the case of $\mathrm{Pb}$, in which a slight decrease of the recovery ratio was observed in the concentration range of $\mathrm{PO}_{4}{ }^{3-}$ higher than $25 \mathrm{mg} / 50 \mathrm{ml}$. The present findings thus demonstrate that interference of $\mathrm{PO}_{4}{ }^{3-}$ on the recoveries of $\mathrm{Cd}, \mathrm{Cu}, \mathrm{Mn}$, and $\mathrm{Pb}$ during determination by the coprecipitation method with $\mathrm{Zr}(\mathrm{OH})_{4}$ is avoidable with the removal of acid-insoluble zirconium phosphate by centrifugation, and this procedure can then widely be utilized to eliminate direct interference by $\mathrm{PO}_{4}{ }^{3-}$ in FAAS by the determination of various methods in samples containing $\mathrm{PO}_{4}{ }^{3-}$.

\section{References}

1) K. Abe, M. Ito, H. Kikuchi, J. Kimura, K. Kumaki, A. Kogawa, E. Kobayashi, K. Sasaki, M. Sakurai, A. Sato, M. Sato, N. Shibata, R. Sugawara, S. Suzuki, Y. Suzuki, T. Seki, M. Takahashi, M. Takeda, I. Chiba, T. Chiba, K. Hiroshima, Y. Mishima, Y. Mihara and K. Yokota, Eisei Kagaku, 33, 258 (1987).

2) B.N. Ames and D.T. Dubin, J. Biol. Chem., 235, 769 (1960).

3) M. Ito, M. Sato, N. Shibata and S. Suzuki, Bunseki Kagaku, 35, 802 (1986). 